\title{
ADAPTATION OF UKRAINE'S LABOR LEGISLATION TO EUROPEAN UNION LEGISLATION: PROBLEMS AND WAYS TO OVERCOME THEM
}

\author{
Olena Kostyuchenko ${ }^{1}$ \\ Olha Hots-Yakovlieva²
}

DOI: https://doi.org/10.30525/978-9934-26-077-3-36

\begin{abstract}
The harmonization of Ukraine's labor legislation with EU legislation requires the embedding of its supranational system of law. To do this, it is necessary to review the role of the state, in particular its judiciary branch in the regulation of relations in the field of labor. It is important that EU legislation which regulates public and private aspects of hired labor gives EU member states the right to independently choose forms and methods of implementation of European standards in private spheres. The arrangement of labor and related relations depends on the ideas of the participants of labor law relations about freedom, justice, equality and humanism. Improvement of Ukraine's labor legislation based on European basic principles and conditions of labor regulation is the main condition for joining the European Union. Simply transferring the norms of European legislation to the national one is impossible since EU legislation differs from the labor legislation of Ukraine regarding the system of its forms. It is also important that EU law is generally a supranational legal system. It is also worth to pay special attention to the fact, that the fundamental rights and socio-economic interests of employees are enshrined in EU regulations, thus they acquire legal certainty. Also, the process of their consolidation, guarantee, implementation, and protection is continuous. EU legislation is characterized by dynamism, as it evolves with the development of society and its ideas of "necessary" and "desirable".
\end{abstract}

\footnotetext{
${ }^{1}$ Doctor of Law, Professor,

Acting Leading Researcher at the Department for Ensuring the Integration of Academic and University Legal Science and the Development of Legal Education, Kyiv Regional Center of the National Academy of Legal Sciences of Ukraine, Ukraine

${ }^{2}$ Candidate of Legal Sciences, Associate Professor,

Associate Professor at Department

of Civil Law Disciplines and Labor Law named after prof. O.I. Protsevskiy,

H.S. Skovoroda Kharkiv National Pedagogical University, Ukraine
} 


\section{Introduction}

Ukraine's choice for European integration is an integral part of the strategy of state's further development accompanied by the implementation of legal reform and adaptation of Ukrainian legislation to European one to implement European experience of regulation of labor relations. However, one should understand that copying and simply transposing international regulations into Ukrainian law will not yield positive results if they do not reflect the real relations in the field of labor. The problems of adaptation of Ukraine's legislation to EU's legislation have become a priority of Ukrainian legal science since the signing of the Association Agreement with the EU [1]. Therefore, the adaptation of home labor legislation to EU law requires the definition of its ways.

\section{The problem of the compatibility of the EU's and Ukraine's labor law forms}

Law as a social phenomenon has its forms which establish rules of conduct for participants in legal relations, including labor and closely related. The problem of law forms mainly concerns the discussion on the proper external reflection of the essence of legal norms. When talking about the objective reasons for the formation of law, one should consider the natural rights of person and the system of existing relations in the field of labor.

In Ukrainian science, the forms of law are mostly considered as an officially recognized acts of external reflection of legal regulations. The main form is a normative legal act, which is a written legal expression of the state's will which contains currently valid legal norms and regulations. It is being approved in special legislative procedure, is protected and sanctioned by the state. National forms of labor law can be classified as follows: 1) Laws of Ukraine; 2) Bylaws of Ukraine; 3) Regulatory agreements; 4) Acts of judicial bodies. In the context of the abovementioned forms of law, the status of judicial practice in the regulation of labor relations deserves special attention. P.I. Zhigalkin, S.M. Prylypko, O.M. Yaroshenko stated: "Changing the role and place of the judiciary in the mechanism of public administration requires a reassessment of the importance of judiciary in the system of legal regulation". The authors noted that the case law is forced to fill in the gaps in labor law, using the of analogy of legal acts or analogy of law i.e., to engage in "law-making" activities [4, p. 17, 19]. 
Thus, the main source in Ukrainian labor law is a normative legal act as an external form of fixing the legal regulations, which is approved at the state level by the authorized body. The regulatory agreements reflect the contractual principles of regulation of labor relations and are aimed at detailing the rules laid down in laws and legal acts. Acts of the judiciary concerning the field of labor, have not been considered as forms of law for a long time. Henceforth it is recognized that judicial precedent is a force of law in Ukraine. The European Court of Human Rights also relies on the principles and norms established earlier by itself as on "sustainable case law" or "precedent" [5, p. 25]. Scholars note that "...the activities of the European Court of Human Rights show that from the very first years of its activities the court largely took into account its legal positions expressed in previous decisions for the sake of interests of legal certainty and predictability of subsequent decisions" [6, p. 19]. In addition, the Law of Ukraine "On Enforcement of Judgments and Application of the Case Law of the European Court of Human Rights" obliges Ukrainian judicial authorities to use the case law of the European Court of Human Rights as a form of law [7]. That is, a judicial precedent must be considered today as a form of home labor law.

Regarding the legal regulation of labor relations in the EU, it is necessary to pay attention to the significant differences between the forms of Ukrainian and EU law. There are two approaches to the forms of EU law in the legal scientific literature. The first substantiates the existence of four main groups: a) regulations; b) general principles of law; c) decisions of the European Court of Human Rights, and d) international treaties. The second distinguishes two groups of legal forms: 1) primary legislation, which is divided into primary and secondary, and 2) secondary legislation - legal acts of institutions and regulations (which, depending on the parties, are divided into three groups: EU agreements with third countries, additional conventions between Member States and interinstitutional agreements). The system of EU law forms consists of founding documents (agreements), first constituent agreements, protocols, declarations and annexes to agreements; conventions; charters; declarations; regulations; directives; decisions; recommendations and conclusions [5, p. 12-20]. As one could note from the above, the forms of EU law differ from the forms of Ukrainian law. At the same time, their specificity is conditioned by the efforts of EU 
member states to harmonize national legislation with Union legislation while respecting the priority of EU legislation and taking into account that the basic areas of European Community law are different, i.e., some countries belong to the so-called "romano-germanic" legal family, other countries - to "anglo-saxon" legal family. European law is a special legal system (sui generis), which exists alongside with national legal systems and international law and differs from them in a number of important features and peculiarities [8, p. 41].

Thus, without the adaptation of national legislation to the legislation of the European Union, it is unlikely to be possible to apply European legal standards in Ukraine to regulate labor relations in modern conditions, because labor relations in the post-Soviet space are formed in a specific economic environment (planned economy), and now socially useful work is based on principles of market economy. As for the correlation of international agreements in the field of labor relations, Ukrainian labor legislation has determined the priority of an international agreement over national legislation. However, this provision does not solve the problems of adaptation of legislation, which complicates the implementation of positive European experience in the field of labor. We believe that the core basis for the adaptation of home labor legislation to EU legislation is the interests of participants of labor relations.

At the present stage of the country's development, labor relations are regulated based on a number of normative legal acts, which set out the conditions for the organization of labor by Ukrainian employers. The Labor Code of Ukraine stipulates that labor legislation regulates labor relations of employees of all enterprises, institutions, organizations, regardless of ownership, type of activity and industry affiliation, as well as persons working under employment contracts with individuals. It should also be noted that the terms of employment contracts that worsen the situation of the employee, compared to the legislation of Ukraine, are invalid. With it, additional labor and social benefits can be established for employees by enterprises, institutions, organizations within their powers and at their own expense. That is, labor law provides ample legal opportunities for the participants of labor law relations in determining the working conditions under the employment contract.

The legislation allows employers to introduce any non-prohibited forms of employment, as well as to determine working conditions, including 
working schedules, working hours and time for rest independently, in compliance with the norm of working hours duration. Given this fact and considering the need to address the issue of adaptation of national labor legislation to EU legislation, we believe that the legislation should pay more attention to the means of fulfillment of labor rights and interests, rather than establishing permits for local regulation. It should be realized that in common theoretical sense, legal regulation is defined as a purposeful impact on human behavior and social relations through special legal means [9, p. 435]. State regulation of labor relations should be carried out by legal means, the functional purpose of which is to ensure the consolidation, guarantee, fulfillment, and protection of the rights and interests of participants in labor relations. Legislation as an instrument of state regulation of relations in the field of labor plays a key role here, and it should change depending on the changing interests of participants in labor relations in the specific conditions of the development of state.

In Ukraine, up to nowadays, labor legislation remains burdened by Soviet ideology, so the task of labor law science is to develop new legal ideas and legal opportunities inherent in law, to realize the right to work and taking into account the social functions of labor law. While reforming Ukrainian labor legislation, it is necessary to clearly understand the extent of mutual requirements of participants in labor relations and determine what needs to be improved in this aspect. Thus, the realization of the ability to work to ensure their lives aligns with the person's interests, and the interests that are being fulfilled in the process of socially useful work is person's natural necessity and need. Therefore, modern labor law should give priority to labor rights and socio-economic interests of the employee. In this context, it is necessary to agree with S.M. Prylypko and O.M. Yaroshenko that "...labor legislation is the only branch of law that can not only directly affect the main productive force - the people who are the bearers of labor, but also protect them during employment as well as unemployment. Under the influence of the system of labor legislation the legal mechanism of employees' social protection is formed" [10, p. 132]. Accordingly, the adaptation of Ukrainian labor legislation should be aimed at satisfying the interests of participants in labor relations in such a way as to enrich the efficient means of protecting the employees, rather than simply transferring EU regulations to the legal system of Ukrainian labor law. In our opinion, the social nature of labor 
rights as a natural human rights is a key prerequisite in the regulation of labor relations. And this necessitates the recognition of the priority of employees' labor rights and interests and improving the quality of working conditions is corresponding the interests of society.

The development of any state is impossible without the labor activity of members of society, employment, and the fulfillment of citizens' right to work. Consequently, the satisfaction of individual and collective interests of the participants of labor relations must take place on a legislative basis, in accordance with the provisions of Article 92 of the Constitution of Ukraine, which establish that only the laws of Ukraine may determine the rights and freedoms of person and citizen as well as guarantees of such rights and freedoms. Therefore, according to the national traditions, the adaptation of Ukrainian labor legislation to EU legislation should take place at the legislative level. The state should establish in the form of a law the legal means to satisfy the interests of participants, defining the necessary type and extent of rights and responsibilities of employees and employers in labor relations. The guarantees of employees' rights established by the state should be recognized as a minimum. In this way, the legitimate interests of the parties of the legal relationship must be enshrined in a democratic state, and labor relations are no exception. Recognition of interests in the law gives them a legal form, and to some extent we can state that the legitimate interests of the participant in the labor relationship is a legal mean of guaranteeing and protection of someone's labor rights. The importance of the legitimate interests, particularly in the field of labor, confirms their legal properties to guarantee and protect the labor and other fundamental social rights of the employee. The basis of the employee's legitimate interests should be the law. The state should not distance itself from recognizing the rights and interests of employees, shifting it to the social partnership or local legal acts, employment contracts, etc.

\section{Legal ways of implementation of gender equality principles in Ukraine's labor legislation based on progressive European approaches}

The interests of employees are key in EU law and, as European practice of legal regulation of labor relations shows, the legal security of these interests is clearly traced in the issues of overcoming gender 
discrimination. Equality between women and men in the EU is enshrined in Directives 2002/73/EC and 76/207/EEC of the European Parliament and of the Council on the implementation of the principle of equality between men and women in matters of employment, vocational training, promotion and working conditions [9]. Directives 2000/43/EC, 2000/78/ EC, 76/207/EEC establish guarantees of gender equality, including the possibility of granting family leave for both sexes, lay down rules on compensation for damage to a victim of discrimination, as well as the right of the discriminated person to apply for help to the relevant nongovernmental structures, etc. [10, p. 25].

In this regard the gender issues in the field of labor relations also need attention in Ukrainian society. The efficient resolution of such issues will contribute to strengthening the rule of law and respect for human rights, regardless of gender. The issue of gender equality and overcoming discrimination on the grounds of sex, according to the ILO, is one of the problems of realization of fundamental principles and rights in the field of labor [11, p. 32-33]. The European Communities and EU have been paying much attention to gender issues at the regulatory level for a long period of time. Thus, Directives 76/207/EEC and 2002/73/EC "On the implementation of the principle of equality between men and women in matters of employment, vocational training, promotion and working conditions" oblige EU Member States at national level: (a) to enforce effective, proportionate and dissuasive sanctions for infringements of the Directive; (b) identify and create such means that provide real and effective compensation or redress for the violation or harm to a person restricted by discrimination, by recovering the rights proportionally to caused damages. Such compensation or reimbursement, as stated in the document, may not be limited to the premature fixation of the maximum limit, unless the employer can prove that the damages caused to the applicant by discrimination is merely a refusal to consider his or her resume; (c) to prohibit direct and indirect discrimination in labor relations [9].

The interpretation of direct and indirect discrimination is reflected in Directive 2000/78/EC of 27 November 2000 which establishes a general framework for equal treatment in employment and occupation. Any harassment, including sexual, is prohibited. In this case, direct 
discrimination is understood as an attitude when one person is treated, was treated, or will be treated worse than another in a similar situation. Indirect discrimination occurs when an obvious neutral condition, criteria or practice has forced a person of a certain religious affiliation or religion, a certain type of disability, a certain age or a certain sexual orientation to find himself or herself in a particularly awkward situation compared to other people [12].

Council Directive 75/117/EEC of 10 February 1975 on the approximation of the laws of the Member States relating to the application of the principle of equal pay for men and women established rules aimed at preventing and eliminating victimization against women and men [13]. In general, these rules prohibit any legislative and administrative measures aimed at differences in the remuneration of men and women. It is emphasized that Member States should take measures to ensure the «principle of equal pay» so that collective agreements, tariff grids, pay regulations and individual employment contracts do not contain provisions that make one employee a victim of his or her gender compared to another regarding the payment for his or her labor for equivalent work performed.

The above-mentioned EU Directives provide the possibility for an employee to protect violated right by appealing to non-governmental organizations. Legal leveling of the position of men and women in employment by guaranteeing family leave for employees of both sexes has become independent in a few EU Directives. At the same time, European scientists emphasize that the issues of discrimination on the grounds of sex are also supplemented by the impact of pregnancy and motherhood on women's work [14, p. 397]. The implementation of such leveling of men and women in the national laws of the EU is guaranteed by enshrining in national labor law the types of leave without differentiating the rights of women and men, i.e., defined employee rights to leave, including those granted to persons regardless of sex.

To protect the rights of women against discrimination in certain life circumstances Council Directive 92/85/EEC «On measures to improve safety and health at work for pregnant employees, employees who have recently given birth or are breastfeeding» was adopted [15]. This Directive contains several state's obligations to provide the necessary conditions for pregnant women and women who have given birth and are breastfeeding. 
The principle restricts the equation of pregnancy and the state of the mother to the painful state. It is determined that such employees are at risk regarding their safety and health. Ensuring the minimization of the impact of the work environment on the health of such employees is the responsibility of the employer (Article 3), and the determination of the level of risk and adverse production factors should be carried out by the relevant national committees on safety, hygiene, and health at work. The provisions of the Directive oblige the state to take the necessary measures to ensure that an employee is aware of the working environment at her workplace and of the risks to her health. In this case, working conditions are determined considering movements and postures, mental and physical fatigue, other types of physical and psychological stress associated with the work performed. The directive prohibits dismissal due to life circumstances such as pregnancy and breastfeeding. An important provision of the Directive is the indication that "pregnant employees", "employees who have given birth" and "employees who are breastfeeding" are interpreted in accordance with national law and practice, which gives a male employee the legal right to enjoy certain rights, related to the birth and care of the child. This regulation sets the minimum duration of maternity leave at 14 consecutive weeks, and the mandatory period of this leave is at least two weeks, divided before and after childbirth (Article 8). At the same time, pregnant women can receive unpaid leave to participate in antenatal care, if such training is carried out during working hours [15]. So, it is a question of women's rights only in cases when it relates to their physiological features, in all other cases there is no differentiation.

In general, while assessing Directive 92/85/EEC, it should be noted that its provisions oblige EU Member States to create at the national level such working conditions for pregnant women and women which will protect their health and the health of the child from exposure to harmful substances and other adverse conditions that may affect the health of both persons (mother and child). It is also important that the regulations do not restrict the state in determining rights solely based on sex, although such rights apply to women, but, for example, the right to prenatal training can potentially be exercised by men. Regarding the prohibition on dismissal, we assume that under certain life circumstances a man raising a child on his own is also entitled to such protection. 
Directive 92/85/EEC is another example of legal levelling of men's and women's status in labor relations, which enshrines not just the proclamation of formal equality, but provides equal status of employees by defining their additional rights. In this case, such rights are not an advantage over the rights of an employee of the opposite sex but are additional in the context of specific life circumstances (actual or physiological). Such equality should be ensured at the level of national legislation, and Ukraine's is no exception.

European legislation on gender equality provides a basis for proposing the following ways to improve Ukrainian legislation in corresponding sphere:

1. To perform a comprehensive review of national labor legislation to change it to gender-neutral legislation and, based on the results of the identified opportunities, to ensure equality of men and women in labor relations on the terms of granting additional rights to persons with family responsibilities. One should have in mind that such changes should not preclude the differentiation of working conditions in the context of the protection of motherhood and childhood. It should be noted that Ukraine is already taking steps in this direction. Thus, on April 15, 2021, the Verkhovna Rada of Ukraine adopted a draft Law "On Amendments to Certain Legislative Acts to Ensure Equal Opportunities for Mother and Father to Care for a Child” № 3695 as of June 19, 2020 [16]. The law should ensure equal opportunities for mothers and fathers to care for their children and combine work with family responsibilities; eliminate legislative gaps that restrict a man's right to parental leave; to create preconditions for strengthening the role of the father in the process of raising children and developing responsible parenting in Ukraine. For example, changes to Art. 179, 181 of the Labor Code of Ukraine and Art. 18,20 of the Law of Ukraine "On Leaves" provide that leave to care for a child until he reaches the age of three is an equal right of each child's parent $[23 ; 24]$.

2. Simultaneously with the improvement of labor legislation to implement state programs and measures to level the legal status of women and men. These programs should be aimed at maintaining the competitiveness of the employee who has returned to work after childcare leave, such as statefunded refresher courses. At the same time, our state today has a developed network of educational institutions that can implement such trainings. 
3. Develop a system of incentives for employers to support people with family responsibilities, e.g., kindergartens, summer camps, etc. Given the key stimulating factor of a market economy - economic benefits, it is probably necessary to introduce such incentives in the national tax system, at least by giving the employer the right to address part of their profit to the development of social infrastructure.

4. Start monitoring activities of hidden forms of discrimination in the field of labor, including on the grounds of sex (e.g., refusal to enter an employment contract, non-payment of due salary, failure to provide guaranteed rights, inducement to dismissal at will in case of pregnancy, etc.).

\section{European Social Charter (revised) as a basic legal act which sets the priority of fundamental social and labor rights of employees}

The development of Ukrainian sovereignty is inextricably linked with the reform of labor legislation and the introduction of European values to the regulation of labor relations. However, Ukraine's significant economic lag behind the developed countries slows down the processes of improving labor legislation and strengthening the legal framework for «decent work». Much of the socio-economic problems are reasoned by unfavorable working conditions in Ukraine and the inability of citizens to earn costs for living by their own work. All this necessitates the analysis of European approaches to the regulation of labor relations and their implementation in Ukraine. Since Ukraine's independence, the regulation of public relations based on progressive international and European experience has increasingly attracted the attention of scholars, but at the legislative level there are uncertain ways to implement progressive ideas in labor relations regulation in national law. Therefore, determining the ways to implement progressive approaches to the regulation of labor relations in the Ukrainian labor legislation remains an urgent scientific and practical goal.

To understand the basic European approaches to the legal regulation of self-employment on the basis of an employment contract, it is necessary to understand the essence of employees' labor rights, which are based on the European Social Charter (revised) [17]. One of the first comprehensive studies of the European Social Charter (revised) in labor law science was the work of M.M. Feskov, who proved that "...the participants of labor 
law relations under this regulation are: employees, migrant workers, family members of migrant workers, employees with family responsibilities, the disabled, employees' representatives, employees' associations, employers' associations, employers" [18, p. 172]. So, the regulation of labor relations according to international norms involves the implementation of the principle of unity and differentiation of legal regulation at least on a basis of its participants.

The document also confirms the European values to the core of human and employee rights as the basis of economic and social progress. At the same time, this legal act reveals the content of labor rights in more detail, and it is important that labor rights are not reduced only to the right of an employee in labor relations. Thus, in addition to labor rights, the right to self-employment is recognized, arising from the profession which someone freely choses for own development. The right to earn costs for living is determined by the right to freely choose a profession.

Independent consolidation in the European Social Charter (revised) has acquired the rights of employees, which can be divided into four groups:

1) rights in the field of labor are associated with the free choice of profession and the creation of conditions for the fulfillment of personal abilities to work: the opportunity to earn living costs in a profession that a person freely chooses; appropriate conditions for vocational guidance aimed at helping a person to choose a profession in accordance with his or her personal abilities and interests, and the right to appropriate conditions for vocational training;

2) labor rights in relation to working conditions: fair, safe and healthy working conditions; any measures to achieve the best possible state of health; the right to special protection of mother at the workplace; the rights of persons with disabilities to social integration and participation in public life (working life is one of the manifestations of public life); the right to information and advice at the enterprise; participation in the definition and improvement of working conditions and environment at the enterprise; protection against unlawful dismissal; protection of their claims in case of bankruptcy of the employer; decent treatment at work, the right of employees with family responsibilities to such working conditions that do not conflict with their family responsibilities; the right to appropriate conditions for the performance of their duties and protection against actions that may harm an employee; 
3) labor rights in relation to fair remuneration: the right to fair remuneration, which provides a sufficient standard of living for an employee and his family members; an employee as a family member has the right to adequate social, legal and economic protection to ensure comprehensive development; protection against poverty and social exclusion. These rights, in our opinion, indicate that fair remuneration is not just remuneration for work at a certain level, but a remuneration that allows an employee and his family members to have access to social benefits and not be alienated from society or the professional community due to lack of material opportunities for development, in particular professional. The impoverishment of employees in Ukraine, in our opinion, is an unprecedented fact in a civilized society, because an employee receives a salary that does not allow to spend money on personal development, but also does not provide a proper, healthy lifestyle of an employee and family;

4) individual and collective rights in the field of labor in relation to freedom of association - the freedom of association in national and international organizations to protect their economic and social interests. It is a matter of principle that the right to associate is not limited to the right to join trade unions and provides a legal opportunity to protect such rights and interests of employees and other organizations; concluding collective agreements; the right to information and consultation during collective redress and, accordingly, this right includes the right to collective redress.

Other rights and principles set out in Part I of the European Social Charter are related to social security, including social protection. It is important that social rights for people who do not work, in our opinion, are directly related not only to the level of welfare of the population, but also to the reward for the performed work. To ensure a decent standard of living such provision requires costs, and therefore the less costs are borne by the state, the more costs are borne by an employee who must provide a sufficient standard of living for the family and vice versa. Under any circumstances, a sufficient standard of living cannot be realized without material and nonmaterial costs. Therefore, we believe that either the state implements a fair policy of social security, especially for unemployed, or narrows the social security and raises wage requirements so that an employee could provide family members at the expense of their work. It seems the only way, and moreover international acts do not outline other European values to social 
and economic progress, where a dignified human existence is the basis for the development of a democratic and equal society.

Let us dwell on certain rights detailed in the European Social Charter (revised). Thus, ensuring the effective exercise of the right to work includes maintaining the highest possible and stable level of employment, with the aim of achieving full employment. It is recognized as the main goal and the most important duty of the state that signed this Charter. It follows that the provision of any other social right defined in this international act is impossible without employment. S.M. Prylypko and O.M. Yaroshenko emphasized that "... achieving social goals of employment policy requires coordination of this policy with other measures of economic and social policy" [19, p. 104]. In our opinion, the requirement for the state to provide employment of the population by all possible means is obvious. And if we do not forget about the prohibition of forced labor, then employment should be provided based on free choice and freedom. At the same time, free choice and freedom of work should not be realized as a choice between several types of work or employers, but as a choice of proposed working conditions that allow a person to realize the ability to work and develop spiritually and culturally, without excluding responsibilities of maintaining disabled family members.

Justice as a criterion of working conditions is enshrined by the EU through: (a) the measure of labor, determined by the length of working time; (b) the inextricable link between increasing productivity and reducing the working week; (c) determination of rest time, which must include paid holidays, annual paid leave of at least four weeks, weekly rest; (d) written information about the responsibilities of an employee; (e) differentiation of working conditions depending on the nature of the work performed or the conditions of its implementation, which must be taken into account and provided with appropriate measures.

"The right to safe and healthy working conditions is considered in the Charter as a joint consultation of the state, employees' and employers' organizations to develop, implement and periodically review national policies in the field of labor protection, occupational hygiene and the working environment. The purpose of such activities is to minimize the causes of risks inherent in the working environment. This right provides, in addition to enshrining the rules of occupational safety and health, as well as 
supervision over their observance and development of occupational hygiene services for prevention in this area and providing advice to all employees on these issues" [20, p. 150]. Such major attention to working conditions and safety at the workplace plays an important role in providing the decent working conditions for the employees.

Europe demonstrates its experience: recognizing the economic inequality between employee and employer, the guarantee and protection of employees' rights is carried out through the control of labor protection at enterprises. Ensuring the labor rights of employees in Europe shows that freedom and democracy in the field of labor can only exist if the participants of labor relationships comply with labor laws and monitor their observance by the relevant authorities. Such an approach to the protection of labor rights by the state should be a guide for Ukraine in the process of reforming its labor legislation. In particular, the state should not distance itself from the problems of violation of labor rights especially in terms of occupational health and safety.

Considering the right to fair remuneration, the principle should be recognized as remuneration for work that provides an employee and his family with a sufficient standard of living. It is also important to enshrine equal pay for women and men and the right to increased remuneration for overtime work. The right to fair remuneration contains reservations on the amount of deductions from wages permitted by law, and the peculiarity of the mechanism of wages determination is established by enshrining the terms of remuneration in collective agreements.

Thus, at the European level the right of participation of groups of employees in distribution of net profit of the enterprise is recognized. Also, the fact that fair remuneration for performed work is realized not only at the level of national laws but also at the level of the collective agreement. And this is the basis to say that at least the parties involved in determining the legal basis of remuneration are: the state, the employer and groups of employees through their legitimate representatives.

At the same time, the right to conclude a collective agreement as a specific right in the field of labor includes forms of social partnership, reference to conciliation and voluntary arbitration mechanisms as legal means of resolving labor disputes and the right to strike in case of irreconcilable conflict of interest between employees and employers. It should also be 
noted that the analyzed regulations do not exhaust the entire legal array of international labor standards. For example, "ILO documents contain standards that are crucial for the adaptation and development of national legislation and creating conditions for the development of social dialogue in labor organization and management while providing some space for defining national standards in this area" [21, p. 129]. That is why, collective forms of protection of employees' economic and social interests are provided with the legal potential of different international regulations including several ILO regulations. That proves the importance and necessity of collective participation of employees through their representatives in determining of working conditions while fulfilling their abilities.

This also confirms that "...the main trends in the development of labor rights at the beginning of the XXI century, in a post-industrial society, are: the unity of private and public principles; integrated approach to basic labor rights and their legal fixation; strengthening the importance of international labor rights standards; prevention of deterioration of employees' position in comparison with the level provided by the current legislation and prohibition of abuse of labor rights; recognition of social dialogue in the field of labor as the main principle of realization of labor rights and freedoms" [22, p. 3].

In general, the basic labor rights of employees, recognized by the EU, show that they are directly related to social rights. Indicative for our study is the fact that the rules that establish the legal basis of self-employment, use concepts such as "fair conditions" and "fair remuneration". In contrast to these definitions, in Ukraine the concepts of "appropriate conditions" and "wages not lower than those specified by law" are used [23]. Regarding the "fair conditions" and "proper conditions" Ukrainian labor legislation does not seem to have any special complaints. "Working conditions" as it is defined in the national labor legislation, mostly correspond to the interpretation given on the international level. The exception exists regarding the provisions of Art. 75 of the Labor Code of Ukraine, Art. 6 of the Law of Ukraine "On Vacations", which enshrine an employee's right to annual paid leave lasting at least 24 calendar days [24; 25], in contrast to the international standard of four weeks, which is equal to 28 days.

Regarding the "fair remuneration" and "wages not lower than those specified by law", there are several fundamental issues that need to be clarified: 
1) the law may set the amount of wages that meets the conditions of fair remuneration. However, the wording in the national legislation makes it possible to deviate from the understanding of fair remuneration, so this provision of the Constitution of Ukraine must be aligned to international standards;

2) "fair remuneration", in contrast to "wages", includes not only wages but also access to public goods that provide a sufficient standard of living. This standard of living with its public goods is noted in Art. 25 of the Universal Declaration of Human Rights [26]. Regarding that, let us assume that the level of access to public goods in the world and in Ukraine, in particular after the Second World War, was low. However, the comparison of modern realities of access to public goods in Europe and Ukraine differs significantly. Unfortunately, this level of access is declining every year in Ukraine due to the gap between the incomes of the richest and the poorest. Therefore, we argue that substituting the concept of "fair remuneration" for "wages not lower than those specified by law" worsens the legal status of employees in relation to established international labor standards and creates opportunities for manipulation of the distribution of net gross income generated by the working population. That, in our opinion, is another argument in favor of the need to revise the current Constitution of Ukraine in terms of the provisions of Art. 43 which regulate the determination of remuneration for work;

3) European labor standards clearly enshrine the right of employees to protect their economic and social interests via trade unions and the right to collective bargaining. Therefore, objectively assessing the labor situation, we emphasize the need to increase the role of trade unions in course of occupational activities of employees. European values to understanding the essence of employees' labor rights do not indicate solely the obligation of the state to provide working conditions that meet the interests of employees. The fact of granting a few collective labor rights to employees suggests that employees must exercise these rights to protect their economic and social interests. rather than waiting for a "gift" from the state or the employer.

While analyzing the domestic legislation on labor rights and interests of employees, it should be noted that today Ukrainian citizens have the legal opportunity to exercise their right to work, but mostly cannot meet their living needs and the needs of their families. And there are several 
reasons for this, in particular: the legally determined minimum wage cannot meet the minimum needs of an employee and family; the number of jobs and the unemployment rate do not increase wages by employers; the outflow of capital from the country does not contribute to the capitalization of the economy and enterprises, and accordingly, employers do not have the financial capacity to increase the material and social security of their employees; the state, having announced a course of decentralization, has removed itself from its obligation to guarantee and protect the labor rights of employees; employees and employers do not have experience of proper implementation of social partnerships, and therefore most of the legal opportunities inherent in labor law at the level of collective bargaining remain unrealized [27, p. 38].

In course of improving of national labor legislation, it is better to start from the point that the natural labor and fundamental social rights of employees must be the core guideline of the legislation. Given that the right to work is natural, the priority in labor legislation should be given the principle of fulfilling the vital needs and interests of an employee. At the same time, the "social component of labor" is an integral part of labor law as it is the common practice in the EU.

"Community social policy was based on treaties and the instruments that follow them: a) the free movement of workers and citizens in general; b) social security for migrant workers and European citizens moving within the EU; c) promoting equality between working men and women; d) the emergence of minimum social standards or standards that ensure simple harmonization of rules, in particular on occupational safety and health; e) development of social dialogue and conclusion of two European collective agreements on childcare leave and part-time work" [28, p. 32].

EU legislation is focused on satisfying the rights and legitimate interests of employees, which should be the basis for Ukraine to adapt its national labor legislation. By improving national legislation through the consolidation, guarantee and protection of employee's interests, we will approach the progressive European experience in regulating labor relations, as well as international standards in the field of human rights. It is important that such international standards are fundamental and based on human dignity and values [29]. Labor rights are no exception. We do agree with the scholars that "...certain requirements for the means of guaranteeing human 
rights can also be standardized (in particular, the positive responsibilities of the state to ensure and protect such rights)" [30, p. 22]. So, the standards in the field of labor as a means of ensuring labor rights and legitimate interests of employees can exist and definetely should be implemented in Ukraine.

\section{Conclusions}

Improving the labor legislation of Ukraine based on European values and legal principles of labor regulation is one of the prerequisites for accession of the country to the European Union. However, a simple transposition of the European legal regulations to the national legislation is impossible because EU legislation differs from Ukraine's labor legislation in terms of several factors (e.g., ways of formation, system of legal forms, basic principles). It is also important that EU law is a supranational legal system.

Changing the role of the judiciary in regulating labor relations is fundamental in the process of harmonization of national labor legislation with EU legislation and the introduction of European values.

Ukrainian labor legislation provides ample legal opportunities for labor law participants to regulate labor relations, but European experience shows that state regulation of labor and closely related relations plays a key role in ensuring labor rights and interests of employees. The fundamental rights and socio-economic interests of employees are enshrined in EU regulations, so they acquire legal certainty, and the process of their consolidation, guarantee, implementation, and protection is ongoing.

To determine efficient ways of adaptation of Ukraine's labor legislation to EU law, further studies of the identified problems should be focused on the analysis of the essence of specific branches of Ukrainian labor law as well as the modern system of national labor legislation while comparing them with the respective EU legislation. There is no need to develop any new specific ways to improve national labor legislation. The experience of the European Union should be applied with regard to the national peculiarities of Ukrainian legal doctrine.

\section{References:}

1. Ughoda pro asociaciju mizh Ukrajinoju, z odnijeji storony, ta Jevropejsjkym Sojuzom, Jevropejsjkym spivtovarystvom $\mathrm{z}$ atomnoji energhiji i jikhnimy derzhavamy-chlenamy, z inshoji storony (2014) [Association Agreement between Ukraine, of the one part, and the European Union, the European Atomic Energy Community 
and their Member States, of the other part]. Official Bulletin of Ukraine, 2014, vol. 75 , art. 2125 .

2. Zhigalkin P.I., Prylypko S.M., Yaroshenko O. M. (2008) Sudova praktyka ta jiji znachennja dlja reghuljuvannja vidnosyn u sferi praci: monoghrafija [Judicial practice and its significance for the regulation of labor relations: monograph]. Kharkiv: FINN. (in Ukrainian)

3. Khutoryan N.M., Baranyuk Yu.V., Drizhchana S.V. and others (2008). Gharmonizacija trudovogho zakonodavstva Ukrajiny iz zakonodavstvom Jevropejsjkogho Sojuzu: monoghrafija [Harmonization of labor legislation of Ukraine with the legislation of the European Union: monograph]. Kyiv: Juryd. Dumka. (in Ukrainian)

4. Serdyuk O.V., Shchokin Yu. V., Yakovyuk I.V. and others (2017). Teorija ta praktyka zastosuvannja Konvenciji pro zakhyst prav ljudyny $i$ osnovopolozhnykh svobod: compendium [Theory and practice of application of the Convention for the Protection of Human Rights and Fundamental Freedoms: a compendium]. Kharkiv: Pravo. (in Ukrainian)

5. Pro vykonannja rishenj ta zastosuvannja praktyky Jevropejsjkogho sudu z prav ljudyny: Zakon Ukrajiny (2006) [On the implementation of decisions and application of the case law of the European Court of Human Rights: Law of Ukraine]. Official Bulletin Of Ukraine, vol. 12, art. 792.

6. Sur N.V. (2006). Pravova integhracija Ukrajiny do Jevropejsjkogho Sojuzu: teoretyko-pravove doslidzhennja [Legal integration of Ukraine into the European Union: theoretical and legal research] (PhD Thesis), Kyiv: Kyiv National University of Internal Affairs.

7. Marchenko M.N. (1998) Obshhaja teorija gosudarstva i prava: akad. kurs: $v 2 t$. [General theory of state and law: Acad. course: in 2 vol.]. M.: Zertsalo, vol. 2. (in Russian)

8. Prylypko S.M., Yaroshenko O.M. (2012). Trudovyj doghovir. Doghovir jak universaljna pravova konstrukcija: monoghrafija [Trudoviy contract. Agreement yak universal legal construction: monograph]. Kharkiv: Law. (in Ukrainian)

9. Directive 2002/73/EC of the European parliament and of the council of 23 September 2002 amending Council Directive 76/207/EEC on the implementation of the principle of equal treatment for men and women as regards access to employment, vocational training and promotion, and working conditions. Official Journal of the European Communities. 05.10.2002. L 269/15 - L 269/20.

10. Human rights (2005). Trudovoe i social'noe pravo Evropejskogo Sojuza: dokumenty i materialy [Labor and social law of the European Union: documents and materials]. M.: Human rights.

11. International Labor Office (2012). Osnovopolagajushhie principy i prava v sfere truda: ot dobrovol'nyh objazatel'stv - k dejstvijam [Fundamental principles and rights in the field of labor: from voluntary obligations to action]. Geneva: International Labor Office.

12. Directive 2000/78/EC of 27 November 2000 establishing a general framework for equal treatment in employment and occupation. Official Journal of the European Communities. 02.12.2000. L 303/16 - L 303/22. 
13. Council Directive 75/117/EEC of 10 February 1975 on the approximation of the laws of the Member States relating to the application of the principle of equal pay for men and women. Official Journal of the European Communities. 19.02.1975. L 45/19 - L 45/20.

14. Steiner J., Woods L. Textbook on EC Law (2000). London: Blackstone Press Limited, lxxxvi. 586 p.

15. Council Directive 92/85/EEC of 19 October 1992 on the introduction of measures to encourage improvements in the safety and health at work of pregnant workers and workers who have recently given birth or are breastfeeding (tenth individual Directive within the meaning of Article 16(1) of Directive 89/391/EEC). Official Journal of the European Communities. 28.11.1992. L 348/1 - L 348/7.

16. Pro vnesennja zmin do dejakykh zakonodavchykh aktiv shhodo zabezpechennja rivnykh mozhlyvostej materi ta batjka na doghljad za dytynoju : Proekt Zakonu Ukrajiny (2020) [On Amendments to Certain Legislative Acts Concerning Ensuring Equal Opportunities for Mothers and Fathers to Care for a Child: Draft Law of Ukraine]. Retrieved from: http://w1.c1.rada.gov.ua/pls/zweb2/webproc 4_1?pf3511=69204 (accessed 20 April 2021).

17. European Social Charter (revised). (1996). Official Bulletin Of Ukraine, vol. 40 , art. 2660.

18. Feskov M.M. (2002). Jevropejsjka socialjna khartija (pereghljanuta) $i$ trudove zakonodavstvo Ukrajiny: pytannja adaptaciji [European Social Charter (revised) and labor legislation of Ukraine: adaptation issues] (PhD Thesis), Odessa: Nat. University of Internal Affairs affairs.

19. Prylypko S.M., Yaroshenko O.M. (2014). Pravo na pracju v systemi prav ljudyny [The right to work in the human rights system]. Law of Ukraine, vol. 6, pp. $102-110$.

20. Kostyuchenko O.Ye. (2018). Pravovi pidkhody do rozkryttja sutnosti trudovykh prav u Jevropejsjkij socialjnij khartiji (pereghljanutij) [Legal approaches to disclosing the essence of labor rights in the European Social Charter (revised)]. Rule of law: International Science Journal, vol. 1, pp. 148-154.

21. Volynets V.V. (2015). Mizhnarodni standarty u sferi reghuljuvannja orghanizacijno-upravlinsjkykh vidnosyn u trudovomu pravi [International standards in the field of regulation of organizational and managerial relations in labor law]. Law and innovation society, vol. 1(4), pp. 126-131.

22. Krasnov Ye.V. (2008). Osnovni trudovi prava: mizhnarodni standarty $i$ zakonodavstvo Ukrajiny [Basic labor rights: international standards and legislation of Ukraine] (PhD Thesis), Odessa: Odessa National Law Academy.

23. Constitution of Ukraine (1996). Information of the Verkhovna Rada of Ukraine, vol. 30. art. 141.

24. Labor Code of Ukraine (1971). Information of the Verkhovna Rada of the USSR, vol. 50, pp. 375.

25. On Leaves: Law of Ukraine (1996). Information of the Verkhovna Rada of Ukraine, 1997, vol. 2, art. 4.

26. Universal Declaration of Human Rights (1948). Official Bulletin Of Ukraine, 2008, vol. 93, art. 3103. 
27. Kostyuchenko O.Ye. (2018). Realizacija socialjnogho pryznachennja trudovogho prava $v$ Ukrajini: monoghrafija [Realization of social purpose of labor law in Ukraine: monograph]. Kharkiv: Law. (in Ukrainian)

28. Omelchenko O.L. (2010). Adaptacija trudovogho zakonodavstva Ukrajiny do zakonodavstva Jevropejsjkogho Sojuzu [Adaptation of labor legislation of Ukraine to the legislation of the European Union] (PhD Thesis), Kyiv: Institute Of State And Law named after V.M. Koretsky.

29. Setting international standards in the field of human rights: UN General Assembly Resolution (1986). Retrieved from: http://docu-ments-dds-y.un.org/doc/ RESOLUTION/GEN/NR0/500/56/IMG/NR050056.pdf?OpenElement

30. Rabinovich P., Venetska O. (2012). Mizhnarodni standarty prav ljudyny: zaghaljni oznaky, klasyfikacija [International human rights standards: general features, classification]. Bulletin of the Academy of Legal Sciences of Ukraine, vol. 4(71), pp. 18-28. 